\title{
The Relationship Between Corporate Social Responsibility and Corporate Financial Performance: A Moderating Effect of Economic Policy Uncertainty
}

\author{
Van-Thi Dao ${ }^{1}$, Manh-Trung Phung ${ }^{1} \&$ Hongwei Cheng ${ }^{2}$ \\ ${ }^{1}$ Faculty of Financial Management, Vietnam Maritime University, Haiphong, Vietnam \\ ${ }^{2}$ School of Bussiness, Sichuan University, Sichuan, China \\ Correspondence: Manh-Trung Phung, Faculty of Financial Management, Vietnam Maritime University, 484 Lach \\ Tray Str., Hai Phong City, Vietnam. Tel: 84-902-620-186. E-mail: pmtrung@ vimaru.edu.vn
}

Received: July 8, 2020

doi:10.5430/ijfr.v11n5p304
Accepted: August 21, 2020

Online Published: October 4, 2020

URL: https://doi.org/10.5430/ijfr.v11n5p304

\begin{abstract}
Within recent decades, researches on corporate social responsibility (CSR) has been receiving more attention over the world. The existing literature on CSR is very diverse, both in evaluating the performance of CSR activities as well as and the relationship between CSR disclosure and firms' outcome. This paper extends the literature of the latter case, that is, not only it aims to purely examine the relationship between CSR disclosure activities and corporate financial performance (CFP), but also consider this nexus under economic policy uncertainty (EPU) context. Our primary data is collected from more than 500 listed companies in the Vietnamese stock market from 2013 through 2017, while secondary data (CSR and EPU) are self-calculated under serial criteria. Our results support the hypothesis that the more companies intensively disclose CSR, the higher financial performance (both ROA and Tobin's Q) they could obtain. More interestingly, we find that while EPU seems to weakly moderate the relationship between CSR disclosure and "internal financial performance" (ROA), it will significantly diminish the effect of CSR toward "external financial performance" (Tobin's Q). The research shed light on an approach to measure CSR disclosure indexes for the emerging market as in Vietnam. Our findings encourage the firm's managers to pay more attention to CSR disclosure activities due to the positive benefit that their firm could obtain and suggest policymakers to maintain a stable economic background for a sustainable market.
\end{abstract}

Keywords: corporate social responsibility (CSR), corporate financial performance (CFP), economic policy uncertainty (EPU), Vietnamese listed company

\section{Introduction}

Within recent decades, corporate social responsibility (CSR) disclosure activities have been increasingly attracting the attention of investors, customers, suppliers, employees, and governments around the world, especially, after some global corporate scandals, such as those of Nike (1997), Gulf of Mexico (2010) and Volkswagen (2015) (Note 1). More recently, some countries have required listed companies to disclose CSR information (Note 2). As such, CSR has become a standard for business management at a global level, with international reference standards set by the United Nations, the European Union (EU), the World Business Council for Sustainable Development (WBCSD), Organization for Economic Co-operation and Development (OECD) and International Labor Organization (ILO) conventions.

Despite the importance of CSR activities, it is still a matter of debate whether these activities benefit or hurt corporate financial performance (Kao et al., 2018; Sardana et al., 2020). The first school, which is institutionalized in capitalism, emphasizes that management processes are nothing but profit maximization, regardless of whether it would result in social irresponsibility. Some traditional studies reveal a negative influence of CSR disclosure activities on corporate financial performance (CFP) and explain this by problems of agency cost theory (Barnea and Rubin, 2010), that is, CRS activities may benefit firm's managers through corporate charity while they would harm stockholders' return due to the CSR disclosure expenses. Reversely, researchers following stakeholders' perspective believe that an increase in social expenditure and disclosure corresponds to the improvement of external relationships (e.g. with other stakeholders, government, consumers, or environmental policymakers). The utility of these activities was evident that not only they can offset but also cheapen operation expenses (Freeman, 1994). 
Researches in CSR, especially in the relationship between CSR disclosure and CFP, has mostly been carried out in developed countries such as the United States, the United Kingdom, Germany, and France. Egri and Ralston (2008) states that almost 30 percent of empirical researches in corporate responsibility is conducted in the United States, while the number of studies in this subject is very limited in developing countries (Chapple et al., 2005). Inasmuch as the diversification in economic, political, and cultural characteristics, the literature in developed countries may not be entirely applicable to developing markets.

As an emerging market, the conflicts between managers and stakeholders are somewhat more detrimental in Vietnam than those in developed countries (Fan et al., 2011). Nonetheless, with the recent introduction of multinational corporations, awareness of the importance of CSR activities has been enhancing. Those companies host many cultural, environmental, human, and ethical activities, such as the "I Love Vietnam Program" of Honda Vietnam, the "Personal Health Education Program" of Unilever Vietnam, the "Congenital heart defect support program" and the "Can Tho bridge collapse victim program" by Vina capital. Additionally, since 2016, some Vietnamese companies voluntarily disclosed CSR reports, such as Bao Viet Group, Hau Giang Pharmaceutical Co., Ltd, FPT Group, Vietnam milk... At the same time, the Ministry of Finance in Vietnam started to require all listed companies to disclose CSR information in annual reports. While many Vietnamese firms have gradually recognized the sweet fruits associated with CSR activities and initiated CSR disclosure, there still exist some avoiding these activities due to its burden on a firm's operating expenditure by accelerating agency cost. The purpose of our paper is, therefore, to provide insight into CSR disclosure activities to promote a greater amount of firms engaging in these social relationships. Our results can be extended to other emerging markets in South East Asia who have a similar technology level and environmental issues.

Since the global financial crisis in 2007, Economic Policy Uncertainty (EPU) has been attracting the involvement of more researchers. Most of them declare that there should be a significant correlation between EPU and the volatility of financial markets (Yao et al., 2020). However, to our knowledge, there are very few studies mentioning the relationship between the three variables: EPU, CSR disclosure, and CFP. In this connection, our research intends to contribute further insight by clarification on the role of EPU in the CSR disclosure-CFP nexus.

As discussed in the context of this research, the awareness of disclosing CSR activities in Vietnam is still controversial. Although some companies have already adopted and developed CSR dimensions to report voluntarily, few listed firms are willing to disclose their CSR statement in annual reports, sustainability reports, and websites with sustainable content. For this reason, we are curious as to whether CSR disclosure activities are a worthy investment endeavor to be pursued by public firms in an emerging market such as Vietnam, especially under a stable political and economic system.

Our study contributes to the extension of literature in both theoretical and practical aspects. Because the originally conceived by Western researchers CSR theories may only be applied to developed countries, who have a huge difference in many extends, such as economic, political, and cultural characteristics as those of emerging markets, the theories, should not directly apply to Vietnam. Our research attempts to flexibly utilize CSR disclosure standards (namely, the GRI indicator set) to the real situation in Vietnam following by building the most appropriate research framework for the study of CSR and CFP. The whole study sheds light on the direction of CSR reports in Vietnam. In particular, there is a need to adopt relevant theories, develop appropriate CSR disclosure measurement indicators, and then clarify the relationship between CSR and CFP. Regarding practical implications, by confirming the benefits of implementing and publicizing social responsibility, the findings of our paper redound to promote businesses to voluntarily exercise their responsibilities to disclose social activities. Additionally, we suggest the importance of maintaining a stable economic policy mechanism to macroeconomic policymakers to lead a sustainable stock market.

The rest of the paper is organized as follows: Section 2 briefly reviews studies on the relation of CSR, CFP, and EPU topics. Section 3 illustrates the methodology utilized for our research. Empirical results and implications are then discussed in Section 4. Finally, we make conclusions in Section 5.

\section{Literature Review}

\subsection{Research on the Relationship Between CSR Disclosure and CFP}

The studies involving the relationship between CSR disclosure (will be refered to as CSR later on) and CFP have diversified into many branches and the findings are controversial. Ullmann (1985) summarizes the conclusions of 13 empirical studies within 13 years, and points out among these, the number of declarations about the positive, negative, and neutral CSR - CFP nexus are 8, 1, and 4, respectively. Similarly, Griffin and Mahon (1997) review a more longitudinal timeline which consists of 51 papers from 1972 to 1994 and points out that there still exists a variation about the role of CSR activities, though the proportion of positive findings is steadily increasing. After 
adopting a more rigorous classification method, more evidence of a positive correlation between the two was found. A commonly identified reason for these diverse and contradictory findings is the measurement issue pertaining to both concepts of interest. It is, therefore, suggested to investigate the measurement approaches for the concepts of CSR and CFP (Galant and Cadez, 2017).

There are only a handful of outstanding papers that include researches related to CSR in Vietnam. As a developing country, there is a lack of context-sensitive researches on CSR in Vietnam, because it is inappropriate to utilize the universal CSR theories, given various cultural, political, and economic specificities (Nguyen et al., 2018). However, along with the diffusion of global CSR certificates, the awareness toward environmental or human issues of domestic firms has improved. Wrana and Revilla Diez (2018) advises policymakers to consider CSR support systems as a means to motivate firms to improve Vietnamese companies' involvement with social activities such as the environment and human rights. Subsequently, there has been a number of managers who express a high degree of positive attitude towards CSR behaviors is increasing. For instance, Thang \& Fassin (2017) observes a positive and significant correlation between internal CSR and organizational commitments related to the employee's work environment. These cultural and historical characteristics also influence the way that a firm's board makes decisions on CSR activities. Hoang et al. (2018) studied the relationship between board diversity on corporate social disclosure (CSD) of listed companies in Vietnam from 2008-2010 and points out that the factor that would influence CSD is not "off-board" but "in-board" diversification. This finding reflects the shareholder's expectations and how they exercise CSR behaviors, which can assist in navigating for regulators and corporate executives.

Recently, Yekini and Ho (2014) studied the relationship between CSR and CFP of the top 20 listed companies in Hanoi and Ho Chi Minh City Stock Exchange (2010-2012). The results show that there is a weak relationship between CSR and CFP of these companies in Vietnam. Vice versa, by exploring the relationship between social responsibility, market orientation (MO), and company efficiency, Long (2015) discloses that CSR, in both aspects, has a positive impact on business performance. This result recommends senior managers, CEOs, and shareholders of Vietnamese companies should raise their awareness of the importance of CSR so that they could improve their competitiveness in the global market.

However, most of the previous empirical studies have a drawback. That is, they consider CSR as a factor that directly impacts the performance of a firm's operation. However, as to the perspective of financial managers, CSR is nothing but information disclosure that should not be an estimator of financial performance. To overcome this problem, we put the relationship between CSR and CFP under a moderating effect of economic factors to reflect both direct and indirect influences. The literature of those economic factors is presented below.

\subsection{Research on EPU}

The negative impact of uncertainty on economic activities has been well documented in the literature. Baker et al. (2016) indicated that the degree of uncertainty of economic policies leads to lower output, investment, and employment rate in both the US economy and in the international environment. In fact, there is no regional or technological border for the impact of an uncertain shock to the outcome of the economy, such as productivity, unemployment, or investment (Gulen and Ion, 2015; Kang et al., 2014; Leduc and Liu, 2016; Rodrik, 1991). The stock market, an important institution of every economy, is also being forced under a high level of EPU. For instance, Pástor and Veronesi (2012), by using a general equilibrium model, features a stock price fall, in general, at the time of declaration of policy changes. Not only does the whole stock market's value decline, the risk premium of the market, in sequence, also leads the individual stock return to be more volatile and interrelated (Pástor and Veronesi, 2013).

In broad term, not only do researches about EPU spread out the term, but also dig into a specific component. One important element should be taken into consideration regarding EPU is political uncertainty. Though it is still a matter of debate whether political uncertainty is part of EPU, researchers are unified in accrediting the negative impact of political risk and uncertainty toward economic factors such as investment and capital diminishing (Jens, 2017; Lensink et al., 2000). Among varieties of sources, fiscal policy, especially tax policy, is judged as the most important factor contributes to political and economic uncertainty (Baker et al., 2016), for example, weaken economy recovery after crises (Kydland and Zarazaga, 2016). Meanwhile, microeconomic factors appear to be more affected by monetary policy uncertainty. Husted et al. (2019); Sinha (2016) and Aghion et al. (2009) focus on the interest rate and currency uncertainty and productivity and explore a depression of those variables on production outputs.

Standing from the perspective of industrial companies, economists have been trying to figure out the optimal solution to face the challenge of uncertainty. During an economic uncertainty period, they suggest firms to raise investment in 
their research and development activities (Vo and Le, 2017). This can be further explained that competitive firms tend to implement preemptive strategies when they face high uncertainty and being supported by the theory of strategic growth options. Other investments, such as hiring, high return futures/options, or capital expenditure should be deduced to maintain firms' financial ability (Caballero, 1991; Gulen and Ion, 2015) until the uncertainty is resolved.

The above argument leads us to a question of whether EPU plays a role in the relationship between CSR and CPF. Therefore, different from the previous studies in this relationship, we treat EPU as a moderating variable and hypothesize that EPU will have both direct and indirect regulatory effects on the firm's financial performance.

\section{Methodology}

\subsection{Research Model}

To examine the impact of CSR on CFP, similar to several previous studies (Harjoto et al., 2015) we estimate the following equation:

$$
\mathrm{CFP}_{i, t}=\eta_{i, t}+\beta * \operatorname{CSR}_{i, t}+\gamma^{\prime} * \mathrm{X}_{i, t}+\varepsilon_{\mathrm{i}, \mathrm{t}}
$$

where $C F P_{i, t}$ is the measure of the corporate financial performance of firm $i$ in year $t ; \eta_{i, t}$ is the firm-year fixed effect that controls all factors that are firm-specific (level of development, geography, institutions, etc.) and time-specific (other factors rather of uncertain economic policies such as changes in regulations, market risks...); $X_{i, t}$ is a matrix of control variables to capture the effect of firm-specific factors such as financial leverage, size, risk, or ownership.

In order to clarify the relationship between social responsibility and CFP, similar to previous empirical studies in developing countries, this study also examines the impact of different aspects of social responsibility on society and the needs of different stakeholders for CFP. Therefore, we also estimate the effect of CSR's components to CFP through 4 equations, respectively.

$$
\mathrm{CFP}_{i, t}=\eta_{i, t}+\beta_{j} * \mathrm{CSR}_{j, i, t}+\gamma^{\prime} * \mathrm{X}_{i, t}+\varepsilon_{\mathrm{i}, \mathrm{t}}
$$

where $j=1 \ldots 4$, and $C F P_{j, i, t}$ corresponds to the jth category of CSR as: environmental responsibility (CSR_ENV), employee responsibility (CSR_EMP), community responsibility (CSR_COM) and the product responsibility (CSR_PRO).

The moderating effect of economic policy uncertainty (EPU) factors is then estimated by the following regression model:

$$
\mathrm{CFP}_{i, t}=\eta_{i, t}+\left(\beta+\gamma * \mathrm{EPU}_{t}\right) * \mathrm{CSR}_{i, t}+\alpha * \mathrm{EPU}_{t}+\gamma^{\prime} * \mathrm{X}_{i, t}+\varepsilon_{\mathrm{i}, \mathrm{t}} ;
$$

Here, $E P U_{t}$ represents for the economic policy uncertainty factors in year t. Because EPU is a macroeconomic variable, it has the same value for all observations in a specific year. Not only is the purpose of this regression to examine the effects of EPU to CFP, but also to explore how these factors moderating the relation between CSR and CFP (through the coefficient of cross-product).

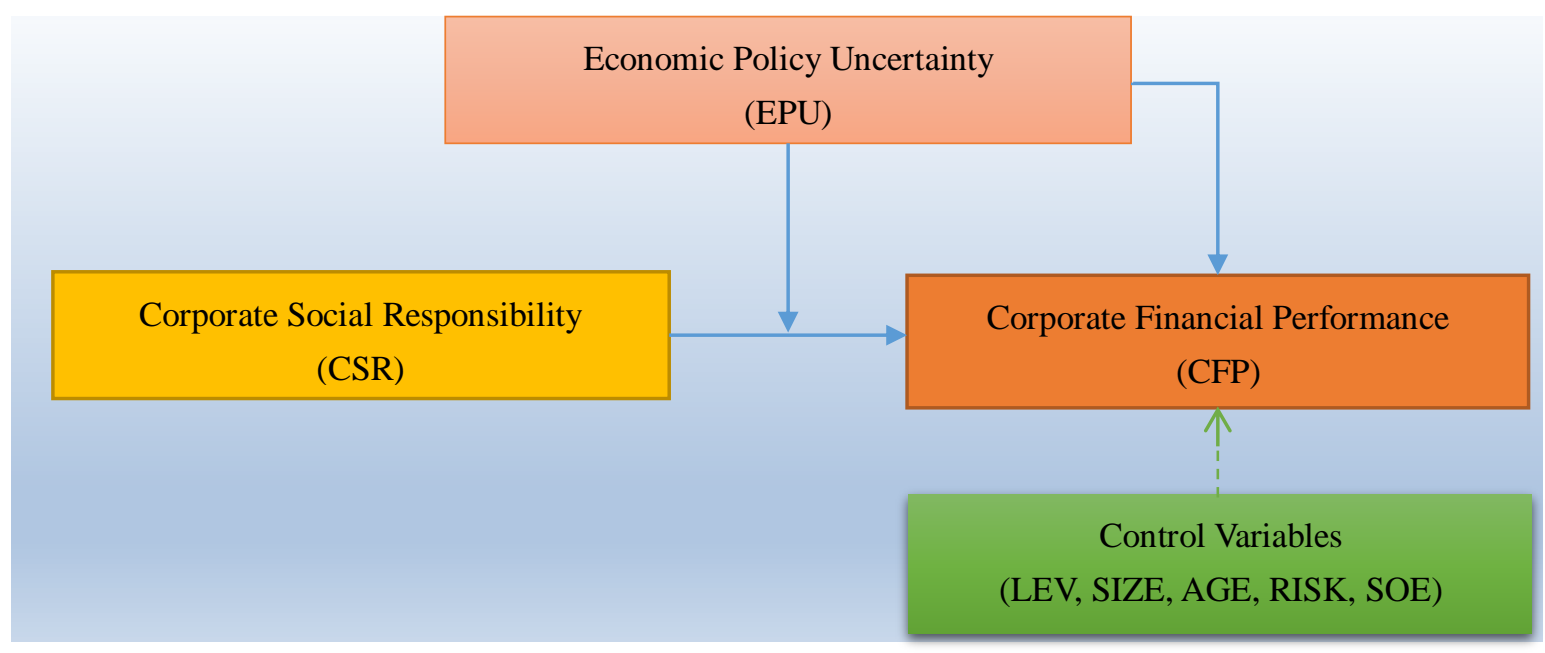

Figure 1. Research framework 


\subsection{Variable Definition}

- Corporate social responsibility (CSR):

There are several ways to measure the CSR index. The first is the reputation index, such as the CEP (The Council of Economic Priorities), the Milton Moskowitz, and the Fortune reputation index. The second is the corporate rating, such as Kinder, Lydenberg and Domini Index (KLD); Dow Jones Sustainability Index (DJSI); Global Initiative Reporting Indicator (GRI); and Domini 400 Social Index (DSI). The third one, related to assessing social responsibility, is carried out through a survey. The final way is to analyze the content of secondary data. Many studies have applied this method to analyze the extent of CSR activities in public companies, especially in their reporting units.

Each measuring method has its pros and cons, and only reflects a certain aspect of social responsibility, that is, considering it to be a proxy variable for social responsibility. This study, therefore, proposes a different approach, incorporating the "GRI-4 Guideline" and the actual situation of Vietnam, - an emerging market, through content analysis to develop social responsibility criteria involving four types of responsibilities. The reason that we use the "GRI-4 Guideline" is that it provides systematic guidance and support for companies willing to publish their CSR activities and sustainable development measures (Brown et al., 2009). These responsibilities include the environment, working, community, and product. Subsequently, the social responsibility criteria are benchmarked and the social responsibility index is developed for developing countries.

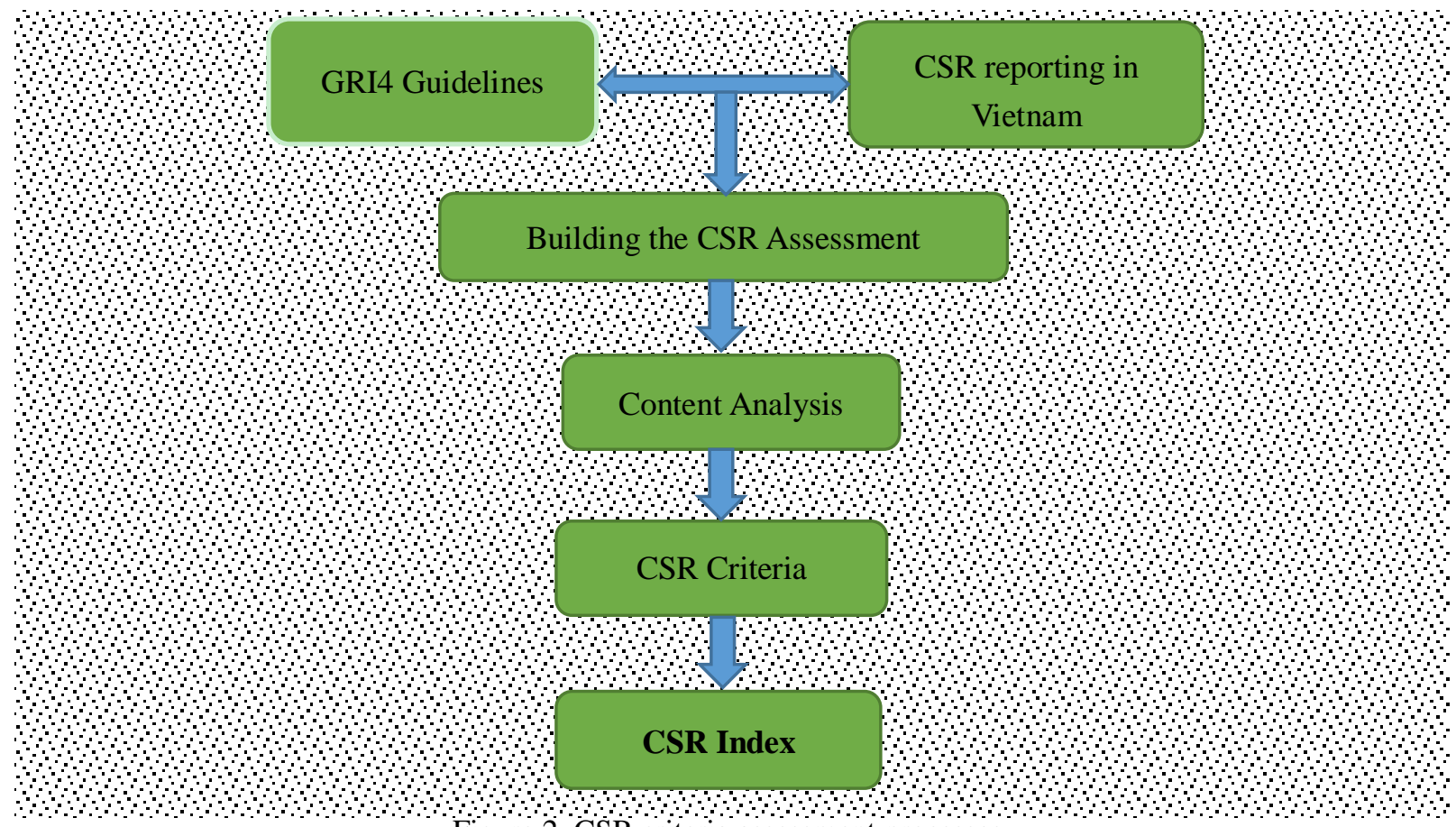

Figure 2 . CSR criteria assessment processes

\section{- Corporate financial performance (CFP):}

Arriving from existing literature, the study adopts accounting and market-based measures to indicate CFP. In detail, the two indicators are ROA and TBQ (Choi et al., 2010; Peters and Mullen, 2009). These two factors are chosen since they are the most common measures to test the relationship between social responsibility and CFP in previous studies that imply profitability, financial structure, and stock price.

- Economic policy uncertainty (EPU):

There are many ways to determine the EPU index. In the context of this study, we adopted the approach of Baker et al. (2016) to develop measurements of EPU in Vietnam. The spirit of our process is to construct a scaled frequency count in articles about policy-related economic uncertainty in the Vietnamnews (VNN), one of the Vietnamese leading English-language newspapers. We first collected all VNN's articles related to at least one term from each of the Vietnamese economic uncertainty information, such as Vietnam, Vietnamese, economy, economic, uncertain, and 
uncertainty. We identified whether the sample articles contain any of the following terms: policy, spending, budget, interest rates, reform, tax, government, Hanoi, authorities, central bank, State Bank of Vietnam, regulation, deficit, and WTO. Finally, we divided the numbers of selected articles in a particular month using the total numbers of all VNN articles in the same month and normalize the resulting series to a mean value of 100 from January 2013 to the most recent by applying a multiplicative factor. The yearly EPU indexes are then calculated by the average of monthly EPU indexes in that year.

- Control variables:

The debates between social responsibility disclosure and financial efficiency are controversial. This nexus is controlled by many factors, such as company size, and age. Kumar et al., (2014) believes that the practice of social responsibility disclosure is related to the size of the firm, as stakeholders expect large companies to participate more effectively in social activities than in smaller ones. Because company size is related to environmental standards, the bigger one is more concerned about their social image, therefore, only small errors in management behaviors can lead to unpredictable consequences, such as product quality, emissions, employment, and so on. Following the spirit of literature, this study utilizes several control variables that could increase the estimated probability of the relationship between social responsibility and CFP, such as (1) Firm size, (2) Financial leverage, (3) Firm Risk, (4) Age and (5) SOE.

\section{Findings and Discussions}

\subsection{Descriptive Statistics}

This study collects a sample based on data of listed companies in Vietnam (using financial reports, annual reports, sustainability reports, etc.). The total number of observations is 592 , corresponding to the total number of enterprises with CSR disclosures for the five years 2013 to 2017. The descriptive statistics of the variables in our sample are as follows:

Table 1. Variable descriptive statistics

\begin{tabular}{|c|c|c|c|c|c|c|c|c|}
\hline Variable & $\mathbf{N}$ & Mean & SD & Min & $\mathbf{P 2 5}$ & P50 & P75 & Max \\
\hline \multicolumn{9}{|c|}{ Financial performance variables } \\
\hline ROA & 592 & 0.071 & 0.091 & -0.517 & 0.024 & 0.058 & 0.104 & 0.784 \\
\hline TBQ & 592 & 1.168 & 0.805 & 0.002 & 0.792 & 1.008 & 1.251 & 9.044 \\
\hline \multicolumn{9}{|c|}{ CSR variables } \\
\hline CSR_ENV & 592 & 0.439 & 0.229 & 0 & 0.250 & 0.375 & 0.625 & 1 \\
\hline CSR_EMP & 592 & 0.764 & 0.148 & 0.166 & 0.666 & 0.833 & 0.833 & 1 \\
\hline CSR_COM & 592 & 0.670 & 0.243 & 0 & 0.400 & 0.600 & 0.800 & 1 \\
\hline CSR_PRO & 592 & 0.576 & 0.248 & 0 & 0.500 & 0.500 & 0.750 & 1 \\
\hline CSR & 592 & 0.587 & 0.155 & 0.142 & 0.485 & 0.576 & 0.683 & 1 \\
\hline \multicolumn{9}{|c|}{ Moderating variable } \\
\hline EPU & 592 & 114.355 & 16.271 & 71.321 & 123.345 & 123.345 & 123.345 & 123.527 \\
\hline \multicolumn{9}{|c|}{ Control variables } \\
\hline LEV & 592 & 0.392 & 0.258 & 0 & 0.166 & 0.378 & 0.590 & 0.984 \\
\hline SIZE & 592 & 3.117 & 1.847 & -1.729 & 1.875 & 2.898 & 4.097 & 9.394 \\
\hline RISK & 592 & 0.576 & 0.540 & 0.096 & 0.302 & 0.387 & 0.568 & 4.342 \\
\hline AGE & 592 & 8.212 & 3.194 & 1 & 7 & 8 & 10 & 18 \\
\hline SOE & 592 & 0.206 & 0.404 & 0 & 0 & 0 & 0 & 1 \\
\hline
\end{tabular}

The average value of CSR_EMP is the largest among the CSR criteria of 0.764. It is reasonable because prior to CSR disclosure under Decision 155 of the Ministry of Finance, enterprises also presented information on employees in accordance with previous regulations. Hence, the information about the employees that the companies publish will be easier and more comprehensive than other information. Only this indicator has the smallest value other than 0 (Min of CSR_EMP = 0.166). Meanwhile, CSR_ENV has the smallest average value $\left(C S R \_E N V=0.439\right)$ in the four components of the total CSR. In fact, the information items from 6.1 to 6.3 in the annual report can be exempt from declarations for enterprises in the finance, banking, insurance and securities industries. Therefore, usually in the 
annual reports of businesses in these industries, there is no information on environmental responsibility.

The two indicators show the CFP of enterprises is ROA and TBQ with an average value of 0.071 and 1.168, respectively. Each indicator has different meanings, with a ROA of 0.071 showing that firms in the sample, the average across the research period, have a return on assets of more than $7 \%$. This figure is a positive sign that businesses are profitable. On the other hand, the fact that the average value of TBQ is 1.168534 implies that the value created by the business is greater than the cost of the enterprise. Regarding the variation, data on the maximum and minimum value of ROA are 0.784 and -0.5172 , respectively with the standard deviation of 0.09 , which shows a very large difference in the profitability index of assets. A similar trend is also discovered with TBQ.

Other control variables, including SIZE, LEV, RISK, AGE, and SOE reveal some interesting insights. The size of the enterprise in the sample varies widely from -1.729 to 9.394 , corresponding to the firm's largest and smallest total asset of 78 billion and 9,964 billion VND. In addition, the minimum and maximum of LEV values are 0 and 0.984 , with an average value of 0.392 . This means that a business does not use a loan while a business uses a loan greater than its total asset value. The average value of SOE is 0.206 , which means that most businesses in the sample are not under State ownership. With the selection of market-oriented mechanisms, Vietnam is gradually transforming former state-owned enterprises into the form of common joint-stock companies. The largest value of AGE is 18 years while the smallest one is 1 year with an average value of 8.212, indicates that the Vietnamese stock market is still emerging and companies have just started their listing.

\subsection{Regression Results}

Our first concern is to explore the impact of CSR on a firm's performance. Using the Stata analysis software, the result of the first regression is summarized in Table 2.

Table 2 indicates that most of the financial performance indexes are significantly positively related to CSR. At a $1 \%$ significance level, CSR is positively correlated with both ROA and TBQ. The regression coefficients of CSR and TBQ are relatively larger (1.445) compared to those of CSR and ROA (0.108). These results provide evidence to confirm the "advocating-CSR" school in previous studies, for example, Nelling and Webb (2009); Ruf et al., (2001); Schreck, (2011).

Table 2. Result of regression of CSR on CFP

Panel A. Regression of CSR on ROA

\begin{tabular}{|c|c|c|c|c|c|}
\hline \multirow[b]{3}{*}{ Variables } & \multicolumn{5}{|c|}{ ROA } \\
\hline & \multirow{2}{*}{$\begin{array}{c}\text { Total } \\
\text { sample } \\
(1)\end{array}$} & \multicolumn{2}{|c|}{ Stock Exchange } & \multicolumn{2}{|c|}{ Industry } \\
\hline & & $\begin{array}{c}\text { HOSE } \\
(2)\end{array}$ & $\begin{array}{l}\text { HNX } \\
\text { (3) }\end{array}$ & $\begin{array}{l}\text { Manufacturing } \\
\text { (4) }\end{array}$ & $\begin{array}{c}\text { Non-Manufacturing } \\
\text { (5) }\end{array}$ \\
\hline CSR & $\begin{array}{c}0.1087 * * * \\
(4.83)\end{array}$ & $\begin{array}{c}0.099 * * * \\
(4.31)\end{array}$ & $\begin{array}{c}0.298 * * * \\
(3.01)\end{array}$ & $\begin{array}{c}0.122 * * * \\
(3.58)\end{array}$ & $\begin{array}{c}0.104 * * * \\
(3.64)\end{array}$ \\
\hline LEV & $\begin{array}{c}-0.1337 * * * \\
(-9.92)\end{array}$ & $\begin{array}{c}-0.128 * * * \\
(-9.24)\end{array}$ & $\begin{array}{c}-0.198 * * * \\
(-3.37)\end{array}$ & $\begin{array}{c}-0.149^{*} \\
(-6.87)\end{array}$ & $\begin{array}{c}-0.130 * * * \\
(-7.91)\end{array}$ \\
\hline SIZE & $\begin{array}{c}-0.0006 \\
(-0.26)\end{array}$ & $\begin{array}{l}-0.002 \\
(-0.93)\end{array}$ & $\begin{array}{l}0.009 \\
(1.66)\end{array}$ & $\begin{array}{c}-0.013 * * * \\
(-2.42)\end{array}$ & $\begin{array}{c}0.0004 \\
(0.20)\end{array}$ \\
\hline INDUS & $\begin{array}{l}0.0146 \\
(1.22)\end{array}$ & $\begin{array}{l}0.011 \\
(0.89)\end{array}$ & $\begin{array}{l}-0.026 \\
(-0.52)\end{array}$ & $\begin{array}{l}-0.007 \\
(-0.16)\end{array}$ & $\begin{array}{l}0.017 \\
(1.33)\end{array}$ \\
\hline RISK & $\begin{array}{l}-0.0056 \\
(-0.87)\end{array}$ & $\begin{array}{l}-0.008 \\
(-1.27)\end{array}$ & $\begin{array}{l}0.021 \\
(0.87)\end{array}$ & $\begin{array}{l}-0.001 \\
(-0.11)\end{array}$ & $\begin{array}{l}-0.007 \\
(-0.99)\end{array}$ \\
\hline AGE & $\begin{array}{l}-0.0003 \\
(-0.32)\end{array}$ & $\begin{array}{l}-0.0003 \\
(-0.32)\end{array}$ & $\begin{array}{l}-0.002 \\
(-0.33)\end{array}$ & $\begin{array}{l}-0.003 \\
(-1.33)\end{array}$ & $\begin{array}{c}-0.0002 \\
(-0.20)\end{array}$ \\
\hline SOE & $\begin{array}{c}-0.0026 \\
(-0.31)\end{array}$ & $\begin{array}{l}-0.002 \\
(-0.24)\end{array}$ & $\begin{array}{l}0.040 \\
(1.09)\end{array}$ & $\begin{array}{l}-0.003 \\
(-0.23)\end{array}$ & $\begin{array}{l}-0.002 \\
(-0.28)\end{array}$ \\
\hline Intercept & $\begin{array}{c}0.055^{* * *} \\
(2.79)\end{array}$ & $\begin{array}{c}0.067 * * * \\
(3.23)\end{array}$ & $\begin{array}{l}-0.022 \\
(-0.28)\end{array}$ & $\begin{array}{c}0.125 * * * \\
(2.27)\end{array}$ & $\begin{array}{c}0.051 * * * \\
(2.26)\end{array}$ \\
\hline Obs & 592 & 555 & 37 & 418 & 174 \\
\hline Adj. $R^{2}$ & 0.188 & 0.180 & 0.507 & 0.3662 & 0.154 \\
\hline
\end{tabular}


Panel B. Regression of CSR on Tobin's Q

\begin{tabular}{|c|c|c|c|c|c|}
\hline \multirow{3}{*}{ Variables } & \multicolumn{5}{|c|}{ Tobin's Q } \\
\hline & \multirow{2}{*}{$\begin{array}{l}\text { Total sample } \\
\text { (1) }\end{array}$} & \multicolumn{2}{|c|}{ Stock Exchange } & \multicolumn{2}{|c|}{ Industry } \\
\hline & & $\begin{array}{c}\text { HOSE } \\
\text { (2) }\end{array}$ & $\begin{array}{c}\text { HNX } \\
(3)\end{array}$ & $\begin{array}{c}\text { Manufacturing } \\
\text { (4) }\end{array}$ & $\begin{array}{c}\text { Non-Manufacturing } \\
\text { (5) }\end{array}$ \\
\hline CSR & $\begin{array}{c}1.445 * * * \\
(6.91)\end{array}$ & $\begin{array}{c}1.182 * * * \\
(6.58)\end{array}$ & $\begin{array}{c}7.607 * * * \\
(4.34)\end{array}$ & $\begin{array}{c}1.54 * * * \\
(4.66)\end{array}$ & $\begin{array}{c}1.365^{* * *} \\
(5.19)\end{array}$ \\
\hline LEV & $\begin{array}{l}-0.195 \\
(-1.56)\end{array}$ & $\begin{array}{c}0.00001 \\
(0.00)\end{array}$ & $\begin{array}{c}-2.369 * * * \\
(-2.27)\end{array}$ & $\begin{array}{c}-0.421 * * * \\
(-1.99)\end{array}$ & $\begin{array}{l}-0.110 \\
(-0.73)\end{array}$ \\
\hline SIZE & $\begin{array}{l}0.018 \\
(0.96)\end{array}$ & $\begin{array}{r}-0.031^{*} \\
(-1.08)\end{array}$ & $\begin{array}{c}0.285 * * * \\
(2.76)\end{array}$ & $\begin{array}{c}-0.0025 \\
(-0.05)\end{array}$ & $\begin{array}{l}0.022 \\
(1.03)\end{array}$ \\
\hline INDUS & $\begin{array}{c}0.177^{*} \\
(1.59)\end{array}$ & $\begin{array}{l}0.067 \\
(0.69)\end{array}$ & $\begin{array}{l}-0.847 \\
(-0.95)\end{array}$ & $\begin{array}{l}-0.062 \\
(-0.14)\end{array}$ & $\begin{array}{l}0.193 \\
(1.59)\end{array}$ \\
\hline RISK & $\begin{array}{c}0.107 * * \\
(1.80)\end{array}$ & $\begin{array}{l}0.067 \\
(1.31)\end{array}$ & $\begin{array}{l}0.263 \\
(0.60)\end{array}$ & $\begin{array}{l}0.146 \\
(1.40)\end{array}$ & $\begin{array}{l}0.095 \\
(1.34)\end{array}$ \\
\hline AGE & $\begin{array}{l}0.005 \\
(0.59)\end{array}$ & $\begin{array}{l}0.001 \\
(0.14)\end{array}$ & $\begin{array}{l}0.047 \\
(0.56)\end{array}$ & $\begin{array}{l}0.018 \\
(1.01)\end{array}$ & $\begin{array}{c}0.0003 \\
(0.03)\end{array}$ \\
\hline SOE & $\begin{array}{c}-0.158 * * * \\
(-2.01)\end{array}$ & $\begin{array}{l}-0.097 \\
(-1.43)\end{array}$ & $\begin{array}{l}0.440 \\
(0.67)\end{array}$ & $\begin{array}{l}-0.164 \\
(-1.29)\end{array}$ & $\begin{array}{l}-0.160^{*} \\
(-1.67)\end{array}$ \\
\hline Intercept & $\begin{array}{l}0.100 \\
(0.54)\end{array}$ & $\begin{array}{c}0.450^{* * *} \\
(2.79)\end{array}$ & $\begin{array}{c}-2.869 * * \\
(-2.00)\end{array}$ & $\begin{array}{l}0.304 \\
(0.56)\end{array}$ & $\begin{array}{l}0.129 \\
(0.61)\end{array}$ \\
\hline Obs & 592 & 555 & 37 & 418 & 174 \\
\hline Adj. $R^{2}$ & 0.1056 & 0.0913 & 0.5931 & 0.219 & 0.0823 \\
\hline
\end{tabular}

Note: $\mathrm{t}$ statistics of regression coefficients are shown in parentheses. All variables are winsorized at the 5\% level; *, $* *$ and $* * *$ indicate significance at the $10 \%, 5 \%$ and $1 \%$ level, respectively.

We also divide our sample into some subsets, as by stock market and by firm's operational characteristic to test the robustness of CSR effects. The column 2,3,4,5 in Panel A and Panel B describe the results of the regression of ROA, TBQ on the values of CSR for different sub-samples. According to the market-based samples, there are 555 firms listed on the Ho Chi Minh stock exchange (HOSE) and 37 on the Ha Noi stock exchange (HNX). It is evident that regardless of which stock exchange firms listed, their CSR information publishing will have a statistically significant positive impact on financial performance. However, HOSE is the bigger and older stock exchange with stricter requirements and disclosure regulations in comparison with HNX. Therefore, it is expected that, on average, firms listed in HOSE will enjoy less benefit corresponding to the same CSR disclosure level of ones listed in HNX. Indeed, our results depict that this impact is lower in HOSE than those in HNX (0.099 vs 0.298 for ROA; and 1.182 vs 7.607 for TBQ).

Regarding the subsets of manufacturing and non-manufacturing firms, we find some statistical evidence that encourages manufacturing firms to enhance their CSR disclosing more than service-firms (the impact of CSR on ROA is 0.122 vs 0.104 and TBQ is 1.548 vs 1.365 for manufacturing and non-manufacturing firms, respectively). As in Vietnam, policymakers believe that manufacturing firms should have more environmental influence, and therefore, require these companies to reveal more details about their activities. Subsequently, the more these companies publish their CSR information, the more easily they attract investment flows and other benefits from the government and investors.

We further assess the impact of CSR components on CFP. The results of the regressions are presented in Table 3. As of expectation, it can be generally seen that all of these components have the same influences toward CFP in the overall CSR index. 
Table 3. Result of regression of CSR's components on CFP

\begin{tabular}{|c|c|c|c|c|c|c|c|c|}
\hline \multirow{2}{*}{ Variables } & \multicolumn{4}{|c|}{ ROA } & \multicolumn{4}{|c|}{ TBQ } \\
\hline & (1) & (2) & (3) & (4) & (5) & (6) & (7) & (8) \\
\hline CSR_ENV & $\begin{array}{c}0.057 * * * \\
(3.76)\end{array}$ & - & - & - & $\begin{array}{c}0.796^{* * *} \\
(5.57)\end{array}$ & - & - & - \\
\hline CSR_EMP & - & $\begin{array}{c}0.051 * * * \\
(2.19)\end{array}$ & - & - & $x^{2}+2$ & $\begin{array}{c}0.705 * * * \\
(3.18)\end{array}$ & - & - \\
\hline CSR_COM & - & - & $\begin{array}{c}0.042 * * * \\
(2.82)\end{array}$ & - & - & - & $\begin{array}{c}0.488 * * * \\
(3.34)\end{array}$ & - \\
\hline CSR_PRO & - & - & $x^{2}+z^{\prime}$ & $\begin{array}{c}0.062 * * * \\
(4.43)\end{array}$ & - & - & - & $\begin{array}{c}0.874 * * * \\
(6.72)\end{array}$ \\
\hline LEV & $\begin{array}{c}-0.132 * * * \\
(-9.74)\end{array}$ & $\begin{array}{c}-0.139 * * * \\
(-10.14)\end{array}$ & $\begin{array}{c}-0.130 * * * \\
(-9.49)\end{array}$ & $\begin{array}{c}-0.139 * * * \\
(-10.31)\end{array}$ & $\begin{array}{l}-0.178 \\
(-1.40)\end{array}$ & $\begin{array}{c}-0.269 * * \\
(-2.08)\end{array}$ & $\begin{array}{l}-0.170 \\
(-1.31)\end{array}$ & $\begin{array}{c}-0.273^{* *} \\
(-2.18)\end{array}$ \\
\hline SIZE & $\begin{array}{c}0.0003 \\
(0.16)\end{array}$ & $\begin{array}{l}0.001 \\
(0.64)\end{array}$ & $\begin{array}{l}0.0005 \\
(-0.26)\end{array}$ & $\begin{array}{l}0.001 \\
(0.63)\end{array}$ & $\begin{array}{l}0.029 \\
(1.53)\end{array}$ & $\begin{array}{c}0.043 * * \\
(2.22)\end{array}$ & $\begin{array}{l}0.022 \\
(1.09)\end{array}$ & $\begin{array}{c}0.042 * * \\
(2.25)\end{array}$ \\
\hline RISK & $\begin{array}{l}-0.005 \\
(-0.80)\end{array}$ & $\begin{array}{l}-0.004 \\
(-0.70)\end{array}$ & $\begin{array}{l}-0.004 \\
(-0.71)\end{array}$ & $\begin{array}{l}-0.005 \\
(-0.82)\end{array}$ & $\begin{array}{l}0.112^{*} \\
(1.86)\end{array}$ & $\begin{array}{c}0.120 * \\
(1.95)\end{array}$ & $\begin{array}{c}0.121 * * \\
(1.97)\end{array}$ & $\begin{array}{l}0.110^{*} \\
(1.585)\end{array}$ \\
\hline AGE & $\begin{array}{c}-0.0001 \\
(-0.11)\end{array}$ & $\begin{array}{c}-0.00003 \\
(0.03)\end{array}$ & $\begin{array}{c}0.00007 \\
(0.07)\end{array}$ & $\begin{array}{c}-0.0003 \\
(-0.35)\end{array}$ & $\begin{array}{l}0.008 \\
(0.87)\end{array}$ & $\begin{array}{l}0.010 \\
(1.07)\end{array}$ & $\begin{array}{c}0.011 \\
(1.14)\end{array}$ & $\begin{array}{c}0.005 \\
(0.5)\end{array}$ \\
\hline SOE & $\begin{array}{l}-0.004 \\
(-0.49)\end{array}$ & $\begin{array}{l}-0.003 \\
(-0.44)\end{array}$ & $\begin{array}{c}-0.004 \\
(-0.5)\end{array}$ & $\begin{array}{l}-0.001 \\
(-0.17)\end{array}$ & $\begin{array}{c}-0.178 * * * \\
(-2.24)\end{array}$ & $\begin{array}{c}-0.173 * * \\
(-2.14)\end{array}$ & $\begin{array}{c}-0.180 * * \\
(-2.23)\end{array}$ & $\begin{array}{c}-0.140 * \\
(-1.78)\end{array}$ \\
\hline Intercept & $\begin{array}{c}0.089 * * * \\
(4.96)\end{array}$ & $\begin{array}{c}0.067 * * * * \\
(2.88)\end{array}$ & $\begin{array}{c}0.081 * * * \\
(4.3)\end{array}$ & $\begin{array}{c}0.079 * * * \\
(4.35)\end{array}$ & $\begin{array}{c}0.538^{* * * *} \\
(3.21)\end{array}$ & $\begin{array}{l}0.250 \\
(1.13)\end{array}$ & $\begin{array}{c}0.493 * * * \\
(2.74)\end{array}$ & $\begin{array}{c}0.400 * * \\
(2.36)\end{array}$ \\
\hline Obs & 592 & 592 & 592 & 592 & 592 & 592 & 592 & 592 \\
\hline Adj. $R^{2}$ & 0.1755 & 0.1625 & 0.1669 & 0.1831 & 0.0813 & 0.0489 & 0.0506 & 0.1019 \\
\hline
\end{tabular}

Note: $\mathrm{t}$ statistics of regression coefficients are shown in parentheses. All variables are winsorized at the 5\% level; *, $* *$ and $* * *$ indicate significance at the $10 \%, 5 \%$ and $1 \%$ level, respectively.

In detail, we first discuss CSR_ENV, which is indicated for more environmental activities. The positive and significant coefficients of this variable $(0.057$ at $1 \%$ significant level) imply that businesses, who have more environmental activities, will increase their financial performance. This advocacy for environmental activities is similar to what was found in Elsayed and Paton (2005); Endrikat et al. (2014); McWilliams and Siegel (2001).

The other dimensions of CSR, namely CSR_EMP, CSR_COM, and CSR_PRO, also have very similar impacts to CFP compared to what of CSR_ENV (both sign and magnitude). This assists us to assert that firms who better aware of matters of employee's issues, community factors, as well as production processes will enjoy more financial benefits (Branco and Rodrigues, 2006; Joshi and Gao, 2009; Kang et al., 2010). In other words, these results once again emphasize the importance of CSR, in every aspect of the activities.

\subsection{Moderating Effects of EPU}

So far, we just concentrated on analyzing the impact of CSR on a firm's financial performance without taking into account the moderating effects of the EPU factor. In this section, we add this factor into our regression to see whether it changes the CSR - CFP nexus. Table 4 shows some interesting results. 
Table 4. Result of regression of CSR on CFP with EPU moderating effects

Panel A. Result of Regression of CSR on ROA with EPU moderating effects

\begin{tabular}{lccccc}
\hline & & \multicolumn{4}{c}{ ROA } \\
\cline { 2 - 6 } Variables & Total sample & \multicolumn{2}{c}{ Stock Exchange } & \multicolumn{2}{c}{ Industry } \\
\cline { 3 - 6 } & $(\mathbf{1})$ & $\mathbf{H O S E}$ & $\mathbf{H N X}$ & $\begin{array}{c}\text { Manufacturing } \\
\mathbf{( 4 )}\end{array}$ & $\begin{array}{c}\text { Non-Manufacturing } \\
\mathbf{( 5 )}\end{array}$ \\
\hline CSR & $0.285^{* *}$ & $0.233^{* * *}$ & $0.240^{* *}$ & $0.362^{* *}$ & $0.362^{* *}$ \\
& $(1.94)$ & $(3.01)$ & $(2.30)$ & $(2.35)$ & $(2.45)$ \\
EPU & 0.0006 & 0.0007 & 0.009 & 0.001 & 0.0006 \\
& $(0.55)$ & $(0.60)$ & $(1.66)$ & $(1.20)$ & $(0.54)$ \\
CSR*EPU & -0.001 & -0.0008 & $-0.016^{* *}$ & -0.002 & -0.002 \\
& $(-0.97)$ & $(-0.68)$ & $(-2.04)$ & $(-1.49)$ & $(-0.98)$ \\
LEV & $-0.160^{* * *}$ & $-0.150^{* * *}$ & $-0.196^{* * *}$ & $-0.181^{* * *}$ & $-0.123^{* * *}$ \\
& $(-7.68)$ & $(-7.13)$ & $(-2.63)$ & $(-9.61)$ & $(-7.13)$ \\
SIZE & -0.0006 & -0.0023 & 0.012 & 0.002 & -0.0007 \\
& $(-0.23)$ & $-0.78)$ & $(1.67)$ & $(0.79)$ & $(-0.31)$ \\
RISK & 0.007 & 0.004 & 0.020 & -0.0009 & -0.006 \\
& $(0.93)$ & $(0.58)$ & $(0.84)$ & $(-0.12)$ & $(-0.71)$ \\
AGE & -.0006 & -0.0007 & -0.001 & 0.00007 & -0.00004 \\
& $(-0.44)$ & $(0.58)$ & $(-0.29)$ & $(0.06)$ & $(-0.04)$ \\
SOE & -0.007 & -0.004 & 0.042 & 0.0001 & -0.002 \\
& $(0.64)$ & $(-0.37)$ & $(1.23)$ & $(0.01)$ & $(-0.22)$ \\
Intercept & -0.016 & -0.139 & -0.126 & -0.098 & -0.029 \\
& $(0.12)$ & $(-0.11)$ & $(-1.69)$ & $(-0.71)$ & $(-0.23)$ \\
\hline Obs & 592 & 555 & 37 & 418 & 174 \\
Adj. $\mathrm{R}^{2}$ & 0.2281 & 0.2186 & 0.4717 & 0.2548 & 0.1272 \\
\hline
\end{tabular}

Panel B. Result of Regression of CSR on Tobin's Q with EPU moderating effects

\begin{tabular}{|c|c|c|c|c|c|}
\hline \multirow[b]{3}{*}{ Variables } & \multicolumn{5}{|c|}{ Tobin's Q } \\
\hline & \multirow{2}{*}{$\begin{array}{c}\text { Total sample } \\
\text { (1) }\end{array}$} & \multicolumn{2}{|c|}{ Stock Exchange } & \multicolumn{2}{|c|}{ Industry } \\
\hline & & $\begin{array}{c}\text { HOSE } \\
(2)\end{array}$ & $\begin{array}{c}\text { HNX } \\
\text { (3) }\end{array}$ & $\begin{array}{l}\text { Manufacturing } \\
\text { (4) }\end{array}$ & $\begin{array}{c}\text { Non-Manufacturing } \\
(5)\end{array}$ \\
\hline$\overline{C S R}$ & $\begin{array}{c}5.261 * * * \\
(3.01)\end{array}$ & $\begin{array}{c}2.331 * * \\
(2.52)\end{array}$ & $\begin{array}{c}8.878 * * * \\
(2.79)\end{array}$ & $\begin{array}{c}6.955 * * * \\
(3.57)\end{array}$ & $\begin{array}{c}6.481 * * * \\
(2.82)\end{array}$ \\
\hline EPU & $\begin{array}{c}0.018^{* *} \\
(2.20)\end{array}$ & $\begin{array}{l}0.005 \\
(0.80)\end{array}$ & $\begin{array}{l}-0.008 \\
(-0.13)\end{array}$ & $\begin{array}{c}0.028 * * * \\
(2.99)\end{array}$ & $\begin{array}{c}0.022 * * \\
(2.18)\end{array}$ \\
\hline CSR*EPU & $\begin{array}{c}-0.032 * * \\
(-2.17)\end{array}$ & $\begin{array}{c}-0.009 * * \\
(-2.76)\end{array}$ & $\begin{array}{c}-0.008 * * \\
(-2.09)\end{array}$ & $\begin{array}{c}-0.047 * * * \\
(2.88)\end{array}$ & $\begin{array}{c}-0.043 * * \\
(-2.25)\end{array}$ \\
\hline LEV & $\begin{array}{c}-0.42 * * * \\
(-2.79)\end{array}$ & $\begin{array}{l}-0.012 \\
(-0.11)\end{array}$ & $\begin{array}{l}-1.925 \\
(-1.51)\end{array}$ & $\begin{array}{l}-0.602 * * * \\
\quad(3.63)\end{array}$ & $\begin{array}{l}-0.130 \\
(-0.82)\end{array}$ \\
\hline SIZE & $\begin{array}{c}0.046 * * \\
(2.12)\end{array}$ & $\begin{array}{l}-0.028 \\
(-1.51)\end{array}$ & $\begin{array}{l}0.242^{*} \\
(1.84)\end{array}$ & $\begin{array}{c}0.067 * * * \\
(2.80)\end{array}$ & $\begin{array}{l}0.027 \\
(1.15)\end{array}$ \\
\hline RISK & $\begin{array}{c}0.134 * * \\
(2.21)\end{array}$ & $\begin{array}{l}0.065 \\
(1.25)\end{array}$ & $\begin{array}{l}0.347 \\
(0.74)\end{array}$ & $\begin{array}{l}0.170 * * * \\
(2.67)\end{array}$ & $\begin{array}{l}0.094 \\
(1.32)\end{array}$ \\
\hline AGE & $\begin{array}{l}0.003 \\
(0.30)\end{array}$ & $\begin{array}{l}0.001 \\
(0.10)\end{array}$ & $\begin{array}{l}0.066 \\
(0.71)\end{array}$ & $\begin{array}{l}-0.001 \\
(-0.15)\end{array}$ & $\begin{array}{c}-0.0004 \\
(-0.03)\end{array}$ \\
\hline SOE & $\begin{array}{c}-0.183 * * \\
(-2.33)\end{array}$ & $\begin{array}{l}-0.098 \\
(-1.45)\end{array}$ & $\begin{array}{l}0.411 \\
(0.61)\end{array}$ & $\begin{array}{c}-0.176 * * \\
(-2.10)\end{array}$ & $\begin{array}{c}-0.160^{*} \\
(-1.68)\end{array}$ \\
\hline Intercept & $\begin{array}{c}-1.904 * \\
(-1.94) \\
\end{array}$ & $\begin{array}{l}-0.215 \\
(-0.25) \\
\end{array}$ & $\begin{array}{l}-2.119 \\
(-0.27) \\
\end{array}$ & $\begin{array}{c}-2.891 * * \\
(-2.58) \\
\end{array}$ & $\begin{array}{c}-2.503 * * \\
(-2.07) \\
\end{array}$ \\
\hline Obs & 592 & 555 & 37 & 418 & 174 \\
\hline Adj. $R^{2}$ & 0.1216 & 0.0924 & 0.5993 & 0.1185 & 0.0923 \\
\hline
\end{tabular}

$* *$ and $* * *$ indicate significance at the $10 \%, 5 \%$ and $1 \%$ level, respectively. 
Firstly, it can be seen that CSR still has a sustainable effect on ROA and TBQ, that is all of the coefficients of CSR variables are positive and significant at least at $5 \%$ of significant level. However, when we consider this relationship in the context of uncertainty, the level of impact is relatively low. This implies that in an emerging market like Vietnam, when the economy becomes more uncertain, in order to ensure better service, firms' managers have to pay more attention to other activities rather than CSR, which is, in turn, dragging down the importance of these responsibilities. Indeed, even though our results do not illustrate the direct impact of EPU on CFP (coefficients of EPU are diverse across CFP variables), economic shocks, to a certain extent, tend to diminish the advantages of CSR activities. More specifically, the betas of cross-product between CSR and EPU are uniquely negative across columns 6 to 10 and ambiguously in columns 1 to 5. Only "external financial performance" is driven down by economic uncertainty and "internal financial ability", in the short term, should not be affected. In most developing countries, EPU factors quantified by information counting are more sensitive to the market price of the company's stocks rather than to its real operation outcomes.

When dividing the research sample by listing location, we see that EPU has negative effects on the relationship between CSR and TBQ (-0.009 for HOSE and -0.008 for HNX). This shows that EPU has the same impact on all types of stocks, regardless of where they are listed. This result is consistent with the system risk theory, that is, systemic hazards will affect all factors in the market (economic policy risk is a general risk or systemic risk). A similar phenomenon is found when we divide our sample by a firm's operational features, that is, for economic shocks, the imagination of manufacturing or non-manufacturing firms both being underestimate by investors.

\subsection{Endogeneity Check}

To explicitly examine the endogeneity issue, we use an endogeneity test in the OLS estimation. That is, we employ the Durbin-Wu-Hausman (DWH) test to verify the consistency of the OLS. Davidson and MacKinnon (1993) suggest an augmented regression test (DWH test), which can easily be formed by including the residuals of each endogenous right-hand-side variable, as a function of all exogenous variables, in a regression of the original model. Because CSR is suspected as an endogenous variable in the equation, we use any exogenous variables in the original regression and add as a new exogenous variable, namely Award, to get residual CSR_res, then perform an augmented regression.

Table 5. OLS augmented regressions of CSR on CFP

\begin{tabular}{ccc}
\hline Variables & ROA & TBQ \\
\hline CSR & $0.2020(1.61)$ & $4.2018^{* * * *(3.61)}$ \\
LEV & $-0.1311^{* * *(-9.44)}$ & $-0.1208(-0.94)$ \\
SIZE & $-0.0023(-0.74)$ & $-0.0337(-1.16)$ \\
INDUS & $0.0070(0.45)$ & $-0.0445(-0.31)$ \\
RISK & $-0.0067(-1.02)$ & $0.0729(1.19)$ \\
AGE & $-0.0007(-0.64)$ & $-0.0071(-0.63)$ \\
SOE & $-0.001(-0.13)$ & $-0.1136(-1.41)$ \\
CSR_res & $-0.0964(-0.75)$ & $-2.8474 * *(-2.41)$ \\
Intercept & $0.016(0.29)$ & $-1.0684^{* * *}(-2.06)$ \\
Observations & 592 & 592 \\
R-square & 0.188 & 0.1144 \\
F & 16.69 & 9.841 \\
\hline P-valued & 0.0000 & 0.0000 \\
\hline
\end{tabular}

The result reveals that when ROA is a dependent variable, the coefficient of CSR_res is not statistically different from zero $\left(P_{-}\right.$valued $\left.=0.451\right)$. In other words, there is no endogeneity bias in this OLS regression. Hence, no need for the instrumental variable. However, when TBQ is considered as dependent variable, CSR_res has a P_valued of 0.016, which implies that CSR is an endogenous variable and OLS estimation is not consistent. Therefore we perform an IV regression on the relationship between TBQ and CSR.

To check if our results are robust, we use two-stage least squares regressions. It is possible that the observed relationship between CSR and TBQ is not due to an actual relationship between these variables, but rather to a third factor that drives both CSR and TBQ. As instruments for CSR, we use the list of Vietnam listed company Awards as 
a dummy variable (Award $=1$ if the company is in the list of Awards otherwise $=0$ ) (Note 3). The rationale behind this instrument is that a firm's CSR is systematically influenced by the Award. Companies that receive annual awards are having good social responsibility reports. The result shows a significant and positive impact of CSR on TBQ. This result is a line with these found earlier from OLS estimations.

Table 6. IV regression on the relationship between TBQ and CSR

\begin{tabular}{cc}
\hline Variables & TBQ \\
\hline CSR & $4.2018^{* * *(3.18)}$ \\
LEV & $-0.1208(-0.83)$ \\
SIZE & $-0.0337(-1.02)$ \\
INDUS & $-0.0445(-0.27)$ \\
RISK & $0.0729(1.05)$ \\
AGE & $-0.0071(-0.56)$ \\
SOE & $-0.1136(-1.24)$ \\
Intercept & $-1.0684 *(-1.81)$ \\
Observations & 592 \\
Wald chi2 & 26.96 \\
\hline P-valued & 0.0000 \\
\hline
\end{tabular}

We also check the strong/weak level of IV variable on the IV regression. The minimum eigenvalue statistic (19.3552 > 10) assists us to conclude that our IV variable is strong, while estimates and tests base on the resulting IV estimator are reliable.

\section{Conclusion}

The main objective of this study is to examine the relationship between CSR disclosure activities and CFP under independent and EPU-moderating-effect contexts. By employing content analysis, we develop the CSR information publishing indexes, for the basis of examining the level of CSR disclosure practiced by Vietnamese listed companies and to explore the motivation of these activities. There have been several studies describing the development of socially responsible framework for developing countries. Nonetheless, this study employs four aspects of CSR (environment, employees, communities, product/customers with 23 operational criteria) in conjunction with GRI4 guidelines, to propose a framework that takes into account the context of Vietnam. Socially responsible practices that vary between countries and cultures (Kao et al., 2018; Sardana et al., 2020) suggest researchers develop CSR frameworks consistently with their national documents and customs.

The study utilizes a variety of panel data analysis techniques to test for our research questions. In detail, to analyze the relationship between CSR and CFP, multivariate regressions were performed for a sample of 592 corporate observations obtained from Vietnamese stock markets (HOSE and HNX) from 2013 to 2017. The results provide empirical evidence that in Vietnam CSR and CFP have a positive correlation. Additionally, all components of CSR also have a significant positive impact on CFP. Last but not the least, this study reveals that as a moderating variable, EPU could drive down the value of TBQ, but stand out of the EPU-ROA nexus. Our findings are consistent with the literature that has been identified from different countries, especially developing markets.

Because of the potential concerns regarding omitted variables and individual heterogeneity, we perform a panel regression analysis. We find that fixed-effects and random-effects results are consistent with those of pooled OLS regressions. Furthermore, the endogenous phenomenon is tested and eliminated to confirm the stability of our results. Future studies may develop a more diverse set of criteria for CSR assessment, control variables that can be strengthened, and CFP indicators that can address other aspects such as level of growth or is the net market value instead of ratios (ROA, TBQ) as in the study. Although there are some limitations, the research has done a great amount of manual work due to data service issues in Vietnam. Through this research, the authors hope to introduce readers to have more concerns and awareness of CSR activities and their positive impact on the performance of businesses. We believe this study will contribute to encouraging policy makers, managers to strengthen CSR activities for a globally sustainable economy. 


\section{References}

Aghion, P., Bacchetta, P., Rancière, R., \& Rogoff, K. (2009). Exchange rate volatility and productivity growth: The role of financial development. Journal of Monetary Economics, 56(4), 494-513. https://doi.org/https://doi.org/10.1016/j.jmoneco.2009.03.015

Baker, S. R., Bloom, N., \& Davis, S. J. (2016). Measuring Economic Policy Uncertainty*. The Quarterly Journal of Economics, 131(4), 1593-1636. https://doi.org/10.1093/qje/qjw024

Barnea, A., \& Rubin, A. (2010). Corporate Social Responsibility as a Conflict Between Shareholders. Journal of Business Ethics, 97(1), 71-86. https://doi.org/10.1007/s10551-010-0496-Z

Branco, M. C., \& Rodrigues, L. L. (2006). Corporate Social Responsibility and Resource-Based Perspectives. Journal of Business Ethics, 69(2), 111-132. https://doi.org/10.1007/s10551-006-9071-z

Brown, H. S., de Jong, M., \& Lessidrenska, T. (2009). The rise of the Global Reporting Initiative: a case of institutional entrepreneurship. $\quad$ Environmental $\quad$ Politics, $\quad 18(2), \quad 182-200$. https://doi.org/10.1080/09644010802682551

Caballero, R. J. (1991). On the Sign of the Investment-Uncertainty Relationship. The American Economic Review, 81(1), 279-288. http://www.jstor.org/stable/2006800

Choi, J.-S., Kwak, Y.-M., \& Choe, C. (2010). Corporate Social Responsibility and Corporate Financial Performance: Evidence from Korea. Australian Journal of Management, 35. https://doi.org/10.1177/0312896210384681

Elsayed, K., \& Paton, D. (2005). The impact of environmental performance on firm performance: static and dynamic panel data evidence. Structural Change and Economic Dynamics, 16(3), 395-412. https://doi.org/https://doi.org/10.1016/j.strueco.2004.04.004

Endrikat, J., Guenther, E., \& Hoppe, H. (2014). Making sense of conflicting empirical findings: A meta-analytic review of the relationship between corporate environmental and financial performance. European Management Journal, 32(5), 735-751. https://doi.org/https://doi.org/10.1016/j.emj.2013.12.004

Fan, J. P. H., Wei, K. C. J., \& Xu, X. (2011). Corporate finance and governance in emerging markets: A selective review and an agenda for future research. Journal of Corporate Finance, 17(2), 207-214. https://doi.org/10.1016/j.jcorpfin.2010.12.001

Freeman, R. E. (1994). The Politics of Stakeholder Theory: Some Future Directions. Business Ethics Quarterly, 4(4), 409-421. https://doi.org/10.2307/3857340

Galant, A., \& Cadez, S. (2017). Corporate social responsibility and financial performance relationship: a review of measurement approaches. Economic Research-Ekonomska Istraživanja, 30(1), 676-693. https://doi.org/10.1080/1331677X.2017.1313122

Griffin, J. J., \& Mahon, J. F. (1997). The corporate social performance and corporate financial performance debate: Twenty-five years of incomparable research. Business and Society, 36(1), 5-31. https://doi.org/10.1177/000765039703600102

Gulen, H., \& Ion, M. (2015). Policy Uncertainty and Corporate Investment. The Review of Financial Studies, 29(3), 523-564. https://doi.org/10.1093/rfs/hhv050

Harjoto, M., Laksmana, I., \& Lee, R. (2015). Board Diversity and Corporate Social Responsibility. Journal of Business Ethics, 132(4), 641-660. https://doi.org/10.1007/s10551-014-2343-0

Hoang, T. C., Abeysekera, I., \& Ma, S. (2018). Board Diversity and Corporate Social Disclosure: Evidence from Vietnam. Journal of Business Ethics, 151(3), 833-852. https://doi.org/10.1007/s10551-016-3260-1

Husted, L., Rogers, J., \& Sun, B. (2019). Monetary policy uncertainty. Journal of Monetary Economics. https://doi.org/https://doi.org/10.1016/j.jmoneco.2019.07.009

Jens, C. E. (2017). Political uncertainty and investment: Causal evidence from U.S. gubernatorial elections. Journal of Financial Economics, 124(3), 563-579. https://doi.org/https://doi.org/10.1016/j.jfineco.2016.01.034

Joshi, P. L., \& Gao, S. (2009). Multinational corporations' corporate social and environmental disclosures (CSED) on web sites. International Journal of Commerce and Management - Int J Commerce Manag, 19, $27-44$. https://doi.org/10.1108/10569210910939654

Kang, K. H., Lee, S., \& Huh, C. (2010). Impacts of positive and negative corporate social responsibility activities on 
company performance in the hospitality industry. International Journal of Hospitality Management, 29(1), 72-82. https://doi.org/https://doi.org/10.1016/j.ijhm.2009.05.006

Kang, W., Lee, K., \& Ratti, R. A. (2014). Economic policy uncertainty and firm-level investment. Journal of Macroeconomics, 39, 42-53. https://doi.org/https://doi.org/10.1016/j.jmacro.2013.10.006

Kao, E. H., Yeh, C. C., Wang, L. H., \& Fung, H. G. (2018). The relationship between CSR and performance: Evidence in China. Pacific-Basin Finance Journal, 51, 155-170. https://doi.org/10.1016/j.pacfin.2018.04.006

Kumar, K., Boesso, G., \& Michelon, G. (2014). How Do Strengths and Weaknesses in Corporate Social Performance Across Different Stakeholder Domains Affect Company Performance?. Business Strategy and the Environment, 25. https://doi.org/10.1002/bse.1874

Kydland, F. E., \& Zarazaga, C. E. J. M. (2016). Fiscal sentiment and the weak recovery from the Great Recession: A quantitative exploration. Journal of Monetary Economics, 79, 109-125. https://doi.org/https://doi.org/10.1016/j.jmoneco.2016.03.002

Leduc, S., \& Liu, Z. (2016). Uncertainty shocks are aggregate demand shocks. Journal of Monetary Economics, 82, 20-35. https://doi.org/https://doi.org/10.1016/j.jmoneco.2016.07.002

Lensink, R., Hermes, N., \& Murinde, V. (2000). Capital Flight and Political Risk. Journal of International Money and Finance, 19, 73-92. https://doi.org/10.1016/S0261-5606(99)00034-0

Long, H. C. (2015). The impact of market orientation and corporate social responsibility on firm performance: Evidence from Vietnam. Academy of Marketing Studies Journal, 19, 265-277.

McWilliams, A., \& Siegel, D. (2001). Corporate Social Responsibility: A Theory of the Firm Perspective. The Academy of Management Review, 26(1), 117-127. https://doi.org/10.2307/259398

Nelling, E., \& Webb, E. (2009). Corporate social responsibility and financial performance: the "virtuous circle" revisited. Review of Quantitative Finance and Accounting, 32(2), 197-209. https://doi.org/10.1007/s11156-008-0090-y

Nguyen, M., Bensemann, J., \& Kelly, S. (2018). Corporate social responsibility (CSR) in Vietnam: a conceptual framework. International Journal of Corporate Social Responsibility, $3(1), 9$. https://doi.org/10.1186/s40991-018-0032-5

Pástor, L., \& Veronesi, P. (2012). Uncertainty about Government Policy and Stock Prices. The Journal of Finance, 67(4), 1219-1264. https://doi.org/10.1111/j.1540-6261.2012.01746.x

Pástor, L., \& Veronesi, P. (2013). Political uncertainty and risk premia. Journal of Financial Economics, 110(3), 520-545. https://doi.org/https://doi.org/10.1016/j.jfineco.2013.08.007

Peters, R., \& Mullen, M. R. (2009). Some evidence of the cumulative effects of corporate social responsibility on financial performance. Journal of Global Business Issues, 3, 1-14.

Rodrik, D. (1991). Policy uncertainty and private investment in developing countries. Journal of Development Economics, 36(2), 229-242. https://doi.org/10.1016/0304-3878(91)90034-S

Ruf, B. M., Muralidhar, K., Brown, R. M., Janney, J. J., \& Paul, K. (2001). An Empirical Investigation of the Relationship Between Change in Corporate Social Performance and Financial Performance: A Stakeholder Theory Perspective. Journal of Business Ethics, 32(2), 143-156. https://doi.org/10.1023/A:1010786912118

Sardana, D., Gupta, N., Kumar, V., \& Terziovski, M. (2020). CSR 'sustainability' practices and firm performance in an emerging economy. Journal of Cleaner Production, 258(10), 120766. https://doi.org/10.1016/J.JCLEPRO.2020.120766

Schreck, P. (2011). Reviewing the Business Case for Corporate Social Responsibility: New Evidence and Analysis. Journal of Business Ethics, 103(2), 167. https://doi.org/10.1007/s10551-011-0867-0

Sinha, A. (2016). Monetary policy uncertainty and investor expectations. Journal of Macroeconomics, 47, 188-199. https://doi.org/https://doi.org/10.1016/j.jmacro.2015.12.001

Thang, N. N., \& Fassin, Y. (2017). The Impact of Internal Corporate Social Responsibility on Organizational Commitment: Evidence from Vietnamese Service Firms. Journal of Asia-Pacific Business, 18(2), 100-116. https://doi.org/10.1080/10599231.2017.1309617

Ullmann, A. A. (1985). Data in Search of a Theory: A Critical Examination of the Relationships among Social 
Performance, Social Disclosure, and Economic Performance of U. S. Firms. The Academy of Management Review, 10(3), 540-557. https://doi.org/10.2307/258135

Vo, L. Van, \& Le, H. T. T. (2017). Strategic growth option, uncertainty, and R\&D investment. International Review of Financial Analysis, 51, 16-24. https://doi.org/https://doi.org/10.1016/j.irfa.2017.03.002

Wrana, J., \& Revilla Diez, J. (2018). Multinational enterprises or the quality of regional institutions - What drives the diffusion of global CSR certificates in a transition economy? Evidence from Vietnam. Journal of Cleaner Production, 186, 168-179. https://doi.org/https://doi.org/10.1016/j.jclepro.2018.03.113

Yao, C. Z., Liu, C., \& Ju, W. J. (2020). Multifractal analysis of the WTI crude oil market, US stock market and EPU. Physica A: Statistical Mechanics and Its Applications. https://doi.org/10.1016/j.physa.2019.124096

Yekini, S., \& Ho, T. (2014). Investigating the link between CSR and Financial Performance - Evidence from Vietnamese Listed Companies. British Journal of Arts and Social Sciences, 17.

\section{Notes}

Note 1. Readers can refer to https://nhbsr.org/blog/2014/02/SchoolPhotoProject.com?page=9 for these events.

Note 2. France (2001), the United States (2003), the United Kingdom (2006), Malaysia (2007), Sweden (2007), China (2008), Denmark (2008) and Vietnam (2016).

Note 3. The Vietnam Listed Company Awards (VLCA) is an extension of the Annual Report poll, the event that has accompanied with the Vietnamese stock market and the community of listed companies in for 10 years (2008-2017). Readers can refer to https://www.aravietnam.vn/ket-qua-binh-chon/nam

\section{Copyrights}

Copyright for this article is retained by the author(s), with first publication rights granted to the journal.

This is an open-access article distributed under the terms and conditions of the Creative Commons Attribution license (http://creativecommons.org/licenses/by/4.0/). 